\title{
A Few Reflections on Accountability
}

\author{
Christian Lund
}

\begin{abstract}
Accountability is a form of communication between people and institutions where one is held to account by the other. Parts of the scholarship distinguish between upward and downward accountability. Upward accountability would involve acknowledgement of an authority to sanction or validate operations or claims, whereas downward accountability refers to the institution of authority being responsible to the general public for their actions. While the directionality of accountability is important, a case from Indonesia suggests that they may indeed be coconstitutive. By deliberately and publicly complying with the idea of state land ownership, and by being selective about what institutions represent 'the state', the farmers used their upward accountability to produce downward accountability in terms of recognition of their rights. The farmers exploited the separation of powers in their attempt to gain a new visibility.
\end{abstract}

Keywords Accountability $\bullet$ Recognition $\bullet$ Social contract $\bullet$ Indonesia

C. Lund $(\bowtie)$

Department of Food and Resource Economics, University of Copenhagen, Copenhagen, Denmark

e-mail: clund@ifro.ku.dk

(C) The Author(s) 2020

S. Sareen (ed.), Enabling Sustainable Energy Transitions, https://doi.org/10.1007/978-3-030-26891-6_5 


\section{Akk ja, retten, retten; hva hjelper det at du har retten når du ikke har noen makt? \\ [Ah yes, rights, rights; what does it help that you have rights when you do not have any power?] \\ —Fru Stockmann in "En Folkefiende" (Henrik Ibsen 1882)}

\subsection{Accountability and Social Contract}

'Everyone realizes how praiseworthy it is for a prince to honour his word and to be straightforward rather than crafty in his dealings; nonetheless contemporary experience shows that princes who have achieved great things have been those who have given their words lightly, who have known how to trick men with their cunning, and who, in the end, have overcome those abiding by honest principles. ... There are two ways of fighting: by law or by force. The first way is natural to men, and the second to beasts. ... a prince must know how to act according to the nature of both, ... he cannot survive otherwise' (Machiavelli 1961: 99). The candour of this sixteenth-century Secretary and Second Chancellor to the Florentine Republic is refreshing. Moreover, his book is probably among the most concise of the 30,000+ offerings from Amazon.com when you punch in 'accountability'. Google.com suggests a menu of 128,000,000 items in less than 0.3 seconds. Power's interest in power is obvious and unabashedly stated as a fact by Machiavelli. It is not cloaked in bureaucratic niceties and unrealistic assumptions about the common good, and as a self-help book for politicians, The Prince remains unsurpassed.

The principle of power stands in tension with the principles of its division. Montesquieu's idea about the separation of powers (1977), Locke's suggestion to rein in tyranny (1980) and Rousseau's doctrine that government must rest on a social contract (1977) all recognise the truths of the drive for power described by Machiavelli, and they all share a concern for the danger of power's concentration. Each, in their own way, suggests checks and balances in the system of government, and within the European history of enlightenment, they may be the first to articulate concern with power's accountability. While Montesquieu focuses on the mutual accountability among institutions of power, Locke and Rousseau direct their attention to the relationship between the governors and the governed. In a nutshell, Rousseau argues that government (or the sovereign) derives its legitimacy to govern from the power freely surrendered by the 
governed in a social contract where the government is elected by the people as a representation of the general will and is therefore accountable to it. The social contract rests on an understanding of mutual recognition between state and citizenry when the population is subject to the laws of the state, and the state is subject to popular political franchise. This figure, however, is as abstract as it is beautiful.

In actual societies, and maybe especially in post-colonial societies, the number of institutions that operate in the name of the state approaches the infinite, and citizenship itself is fraught with intersecting qualifications derived from gender, race and caste, as well as class, creed and conviction (Lund 2016). In terms of social contract, this raises the question: as what are the contractual partners recognised? Who is visible to what institution, and what institution commands authority in what domain? A way to access the empirical complexity may be on offer from a broad philosophical tradition that takes recognition as a fundamental human expression of acknowledgement of the 'other' (Arendt 1973; Fraser 2001; Honneth 1996; Taylor 1989, 1994). Honneth, in particular, talks about visibility among and between actors, and I believe it can be extended to institutions. Social contracts of recognition require mutual visibility between actors and institutions. Actors must have a social, legal, fiscal or cultural presence visible and acknowledged by an institution, and the institution must legitimately appear capable of providing the desired recognition of a claim (Weber 1958). What actors are therefore comprises not individual features but relational, politically visible attributes. So, who is the actor? A tax payer, a peasant, or a red troublemaker, an indigene, a businessman, or a person without paper? And who defines the categories? And, similarly, we must ask what is the specific institution? Executive, legislative or judiciary, or can it be re-purposed to fit the task at hand?

This may seem a somewhat grandiose introduction to what is often seen as a governance routine question. I, however, suggest that any granular analysis of relations of accountability (Latour 2009; Strathern 2000) could do worse than to focus on power, its separation, the mutual recognition of claims and authority, and the representation of rights subjects (or citizens) and government. In the following, I present a summary case from my work in Indonesia to illustrate relations of mutual recognition (Lund 2020). While the case itself relates only indirectly to energy transitions, it surfaces concerns of conflict over land and forest that are germane to any discussion of energy transitions, not least given Indonesia's participation in a global carbon forestry programme (cf. Hein 2018). 


\subsection{Visibility AND ReCOGNITION IN INDONESIA}

Harumandala is a village in West Java in Indonesia. The village consists of several sub-villages or kampungs and is located within a steeply sloped landscape. After independence in 1945, the area saw many confrontations over land control between the Indonesian army and Communist groupings. The confrontations died down around 1961. The area was formally under the territorial authority of the Provincial Forestry Service of West Java, and the entire area was classified as 'forest'. However, most of the area was, in fact, populated with villages and kampungs. Generally, people were farming paddy rice on terraces, as well as different crops on forest plots. In practice, people could clear land for paddy rice farming and other activities without much interference from the authorities. No legal rights ensured people's access to land, but the Provincial Forestry Service tolerated farming and people regarded the land as their own.

In 1978, all the forestland controlled by the Provincial Forestry Service in West Java-close to a million hectares-was transferred to the State Forestry Corporation which had previously operated only in Central and East Java (Peluso 1992; Rachman 2011). As a parastatal institution with its own uniformed 'forest police', and as a part of an authoritarian regime, the State Forest Corporation was inaccessible to ordinary people seeking to argue or negotiate their case. The Corporation established boundaries to create teak and mahogany plantations, clearing the area of any farmed fields that might be in the way. Moreover, it started to act as a landlord charging rent for the fields people cultivated within the area. These farmers thus became tenants of the Corporation, and in the process consolidated its land control. The rent consisted of 33 per cent of the villagers' rice production: There was no legal basis for this rent, and it was never registered as official income of the company.

During the late 1990s, agrarian protest became ever more frequent as the Suharto regime spiralled into decline and crisis. Different social organisations, groups and movements were formed in a period of political transformation in Indonesia. Democratisation and decentralisation appeared to offer opportunities to transform society, and not least the agrarian structures. The protests were accompanied by land occupations, where farmers seized land from state forests or private and government plantations. The occupations were controversial. On the one hand, they were condoned and even hailed by popular movements as the realisation of the longawaited land reform. On the other hand, government condemned occupations as theft (Lucas and Warren 2013). 
In 2006, farmers and their organisation, Sundanese Peasant's Movement (Serikat Petani Pasundan [SPP]) realised that the Forest Corporation's collection of rent was illegal, and actions towards land reform could be launched. The first move was to refuse to pay rent to the State Forest Corporation. Instead, people paid 10,000 Rupiah (equivalent to a couple of US dollars) per month to SPP and turned their presence into a land occupation.

The West Java police commander and the Corporation director in Jakarta decided to re-establish the Corporation's control over the occupied forestlands by launching a so-called forest security operation funded by the Ministry of Forestry. The operation was preceded by a joint reconnaissance for forest security control conducted in March 2008. The State Forest Corporation provided the reconnaissance team with a detailed map that indicated 'forest security disturbances'. The team reported that approximately 290 hectares of forestland were occupied by nearly 1600 villagers from four villages within the district.

Three months after this reconnaissance report was issued, the West Java Police, the Ministry of Forestry and the State Forest Corporation launched a forest security operation. The main objectives of the operation were to re-establish control of the state forestland and to evict the people occupying it. The operation invoked the military terms, Security Operation and Dangerous Area, echoing the Suharto era. Similarly, the use of terms like 'illegal loggers', 'illegal occupiers', 'subversive' and 'anti-state' established an association between land occupation and organised crime. For a country the size of Indonesia, 290 hectares may seem trivial, but the significance of a successful occupation could be earth-shattering, literally breaking new ground for further challenges to state authority.

Officers from the State Forest Corporation and the Provincial Police came to Harumandala and its six kampungs, and more than 300 police officers set up camp and began to prepare the evictions. The operation was initiated by a ceremony, in which the police commander, the head of the Corporation's forest police and representatives from the local government Forestry and Plantation Unit went through the objectives of the operation-namely, to find evidence of illegal logging, to evict illegal occupants and destroy their farms and to remove any illegal construction from the area. First, the police and the Corporation officers made house-to-house searches for timber. Then, fields were ravaged and houses were burnt to the ground. Some houses were left standing, but the police marked them with chalk 'This house must be destroyed by yourself', or 'This house and 
land is not yours but the property of the state'. Finally, the police forced the villagers to sign a statement in which they renounced their membership of SPP and declared they would never join again. It is well worth recalling that this took place almost a decade into the post-New Order democratic era, and that SPP was a legal organisation.

After the police operation, people resumed the cultivation of their plots within the area but moved to kampungs outside of the State Forest Corporation area for a couple of years. By 2010, people had begun to move back to the abandoned kampung of Pasir Pilar within the Corporation-controlled area. People reconstructed their houses; and within six months, some 34 families had re-established themselves in the kampung. The local SPP chapter drew up a map of the area, registering each plot and its owner.

The State Forest Corporation contacted the settlement, but now with a new approach. They announced a planting ceremony of mahogany trees and invited villagers to witness. An area was cleared and 1000 seedlings were planted in rows. Each row was publicly named after a government institution. Thus, the first row was named, 'the row of the provincial governor', the next, 'the row of the police commander', 'the row of the Indonesian army' and so on. The intention, no doubt, was to impress upon the people of the area that these resources belonged to and were under the protection of the entire government structure of Indonesia. The State Forest Corporation had the whole episode filmed. The following night, however, all 1000 mahogany seedlings were uprooted. People remained in their kampungs on the disputed land; they resumed farming their plots and rice fields, and they continued not to pay rent to the State Forest Corporation. They were not beholden to the Corporation or the Indonesian government for their land rights. Instead, they held land thanks to 'the republic' of SPP, with the opportunities and dangers this implied.

As people moved back into their settlement, they asked the official local territorial administration - the village office-for new ID cards that would reflect this change. This was done. By that token, the settlement became an official kampung, situated within the area that the State Forest Corporation claimed to control as forest. Moreover, as people registered to vote for the 2014 elections, officials from the sub-district would visit all houses and place an official government sticker on the door with the name of the voter, and place of residence-their new official kampung. 
The system of payment to SPP remained provisory, but with the smallholders' return to the contested lands in 2010, all kampungs of Harumandala also began to contribute to the Village Office to the tune of 1,000,000 Rupiah annually. At first, the Village Office, its mayor and its elected parliamentarians were reluctant to receive the funds. They were unsure whether they were entitled to recover tax, and what it would mean to accept it, but after some negotiation the Village Government of Harumandala accepted the money at a public ceremony. While still perceived as illegal occupants by the State Forest Corporation, smallholders were also beginning to be seen as taxpaying, voting, registered, Indonesian citizens. Their 'contribution', or tax, established a new substantive relationship between them as landholders and the formal structures of the Indonesian government at its lowest level, the Village Office. It remains to be seen what this new relationship represents. One might argue that this relationship not only established the SPP landholders as owners of property in the eyes of the Village Office; it also established the Village Office as a public authority on questions of property in land that was classified as forest. As the smallholders made claims to resources, they also invoked public authority in the Village Office. Tax collection attributed to it governing capacity and the authority to validate land claims. This may, eventually, put the Village Office in competition with other statutory institutions.

\subsection{REFLECTIONS}

Accountability is a form of communication between people and institutions where one is held to account by the other. Parts of the scholarship distinguish between upward and downward accountability (Fox 2018). Upward accountability would involve acknowledgement of an authority to sanction or validate operations or claims, whereas downward accountability refers to the institution of authority being responsible to the general public for their actions. While the directionality of accountability is important, the case from Indonesia suggests that they may indeed be coconstitutive. When the villagers shifted from payment of rent as tenants to one part of government (the Corporation), to payment of a community tax to another part of government (the lowest level assembly and government), they not only morphed from undercover tenants to enfranchised citizens, but also invoked capacities in the village government that it had not had before. By deliberately and publicly complying with the idea of 
state land ownership, and by being selective about what institutions represent 'the state', the farmers used their upward accountability to produce downward accountability in terms of recognition of their rights. The farmers exploited the separation (or multi-location) of powers in their attempt to gain a new visibility.

The power to define subjectivity - to define it for oneself or to impose it on others - is essential in any relation of accountability, because it defines actors' visibility and, consequently, the possible fields of engagement and contracts of recognition. The Ministry of Forestry and the State Forest Corporation had been long established as the consequential authorities holding the power to define who is entitled and who is a thief. Yet, the active re-orientation by the farmers re-drew the map of mutual recognition. To be sure, this relied on people's capacity and political space to recast themselves as responsible citizens and rights subjects rather than passively being defined as subversive squatters and enemies of the state.

Actors have different capacities to engage in the field of politics. However, the field itself is a result of engagement, not only by the powerful but also by those who resist and want change. This desire for changeexpressed through local politics of land-may, in E.P. Thompson's words (1963: 12), be foolhardy. But the desire for change defines agency and is hardly inconsequential for the relations between people and institutions.

\section{REFERENCES}

Arendt, H. (1973 [1951]). The origins of totalitarianism. New York: Harcourt Brace Janovich.

Fox, J. (2018). The political construction of accountability keywords. IDS Bulletin, $49(2), 65-80$.

Fraser, N. (2001). Recognition without ethics? Theory, Culture and Society, $18(2-3), 21-42$.

Hein, J. I. (2018). Political ecology of REDD+ in Indonesia: Agrarian conflicts and forest carbon. Abingdon and New York: Routledge.

Honneth, A. (1996). The struggle for recognition. The moral grammar of social conflict. Cambridge: Polity Press.

Ibsen, H. (1882). En Folkefiende [An Enemy of the People]. Oslo: Gyldendal.

Latour, B. (2009). The making of law: An ethnography of the Conseil d'Etat. Cambridge: Polity.

Locke, J. (1980 [1689]). Two treatises of government. Cambridge: Cambridge University Press. 
Lucas, A., \& Warren, C. (Eds.). (2013). Land for the people: The state and Agrarian conflict in Indonesia. Columbus, OH: Ohio University Press.

Lund, C. (2016). Rule and rupture. State formation through the production of property and citizenship. Development and Change, 47(6), 1199-1228.

Lund, C. (2020). Nine-tenths of the law. Enduring dispossession in Indonesia. New Haven, Yale University Press.

Machiavelli, N. (1961 [ca. 1532]). The Prince. London: Penguin.

Montesquieu, C.-L. (1977 [1748]). The spirit of the laws. Berkeley: University of California Press.

Peluso, N. L. (1992). Rich forests, poor people. Resource control and resistance in Java. Berkeley: University of California Press.

Rachman, N. F. (2011). The resurgence of land reform policy and Agrarian movements in Indonesia. PhD thesis, University of California, Berkeley.

Rousseau, J.-J. (1977 [1762]). Du contrat social. Paris: Éditions du Seuil.

Strathern, M. (2000). Audit cultures. Anthropological studies in accountability, ethics and the academy. London: Routledge.

Taylor, C. (1989). Sources of the self. The making of modern identity. Cambridge: Cambridge University Press.

Taylor, C. (1994). The politics of recognition. In A. Gutmann (Ed.), Multiculturalism (pp. 107-148). Princeton, NJ: Princeton University Press.

Thompson, E. P. (1963). The making of the English working class. London: Penguin.

Weber, M. (1958). From Max Weber. Essays in sociology (H. Gerth \& C. W. Mills, Eds.). New York: Oxford University Press. 
Open Access This chapter is licensed under the terms of the Creative Commons Attribution 4.0 International License (http://creativecommons.org/licenses/ by $/ 4.0 /$ ), which permits use, sharing, adaptation, distribution and reproduction in any medium or format, as long as you give appropriate credit to the original author(s) and the source, provide a link to the Creative Commons licence and indicate if changes were made.

The images or other third party material in this chapter are included in the chapter's Creative Commons licence, unless indicated otherwise in a credit line to the material. If material is not included in the chapter's Creative Commons licence and your intended use is not permitted by statutory regulation or exceeds the permitted use, you will need to obtain permission directly from the copyright holder.

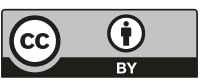

